\title{
Design and sizing of solar PV plant for an electric bus depot in Malaysia
}

\author{
Shah Mohammad Mominul Islam ${ }^{1}$, Arshad Adam Salema ${ }^{1, *}$ and Joanne Mun-Yee Lim ${ }^{1}$ \\ ${ }^{1}$ School of Engineering, Monash University Malaysia, 47500 Bandar Sunway, Malaysia
}

\begin{abstract}
Electric buses consume a high amount of electricity during the charging process, resulting in a high maximum demand (MD) that leads to high operational cost and emissions. Therefore, the aim was to use solar energy to reduce the MD. The off-grid solar PV plant has been designed and sized based on the MD data of the bus depot. The results include the number of PV modules; area required to install the PV modules; sizing of the balance of system. For example, about 7350 modules, 1200 flooded deep cycle batteries, $760 \mathrm{~kW}$ inverter size, 566 MPPT smart solar charge controllers and 23,200 $\mathrm{m}^{2}$ (5.73 acres) area are needed to offset $466.5 \mathrm{~kW}$ of MD.
\end{abstract}

\section{Introduction}

The electricity consumption of Malaysia has increased by almost $65 \%$ in the year 2016 (114 TWh) as compared to 2008 (92 TWh). However, most of this energy comes from fossil fuels such as coal and natural gas [1]. Specifically, the Malaysian transportation sector heavily relies on petroleum products and generates about 70 million metric tons of $\mathrm{CO}_{2}$ emission per year [2]. One significant contributor to this emission is road transport. Therefore, green and renewable-based mobility is now a priority across the world to revolutionise the transportation sector by reducing the dependency on fossil fuels and a detrimental impact on the environment. One such example is the electric buses. Although electric vehicles are a promising choice to achieve sustainable development, however charging these vehicles are still from fossil fuel power plants. Malaysia has intended to present 100,000 units of electric vehicles and 2000 electric buses by 2030 with the capacity of national car company [3]. The power demands for charging the 100,000 units of electric vehicles (EV) is $3300 \mathrm{MW}$ per $160 \mathrm{~km}$ travelling [4].

One of the alternative ways to reduce the dependency on the conventional grid is to use a renewable source of energy such as solar. Previous studies have designed solar PV system for electric vehicles, for example, a feasibility study in China showed that solar PV system could generate $55 \%$ of the energy required for bus charging and cost of electricity per kWh can be lowered as compared to the grid price [5]. Another feasibility study in Bangladesh reported that about $23 \%$ of electricity generated from the solar PV system was used to charge the $\mathrm{EV}$, and the rest was sold to the national grid [6].

Applying solar energy can help to shave off the MD to some extent that can decrease both cost of electricity as well as the carbon emissions in the long term. Therefore, the present research work aims to design and size the off-grid solar PV system for the electric bus depot in Malaysia. The design and sizing were based on the MD consumption and included both solar PV modules and balance of the system.

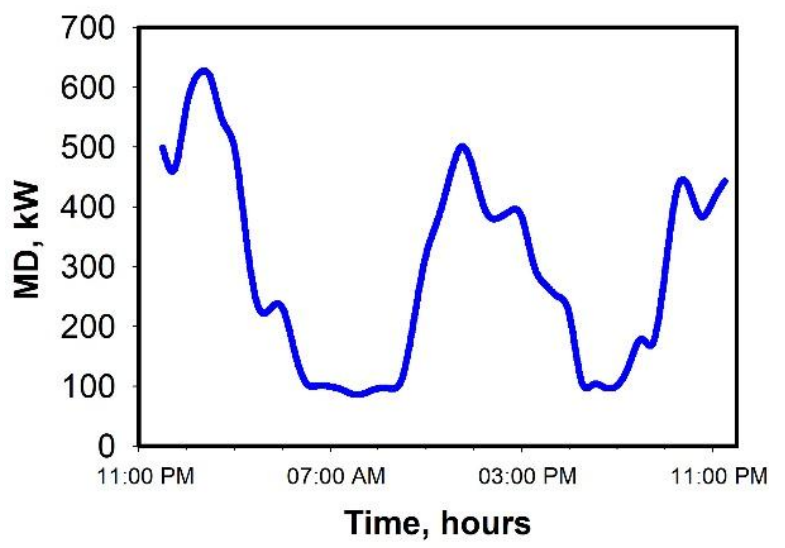

Fig. 1. Typical MD profile of the electric bus depot in Malaysia.

\section{Energy demand for electric bus depot}

Maximum demand (MD) occurs during the charging process of the electric buses and MD has a higher rate per $\mathrm{kW}(30.1 \mathrm{RM} / \mathrm{kW})$. Figure 1 shows the typical MD profile of the electric bus depot. The high peaks in the night ( $9 \mathrm{pm}$ to $3 \mathrm{am}$ ) and day (11 am to $5 \mathrm{pm})$ time are due to charging the buses (total 12 hours). About 6 buses are charged in the night time and 4 in the day time. The highest $(622 \mathrm{~kW})$ MD was taken for the present study.

However, it should be noted that according to policy and regulation, only $75 \%$ of MD can be reduced using

Corresponding author: arshad.salema@monash.edu 
renewable energy. Therefore, about $(622 \times 0.75)=466.5$ $\mathrm{kW}$ MD can be shaved off using solar energy. The solar PV system was designed and sized according to the standards of the Sustainable Energy Development Authority (SEDA), Malaysia.

Table 1. Load assessment parameters and calculation.

\begin{tabular}{|c|c|c|c|}
\hline Parameters & Values & Unit & Calculation \\
\hline $\begin{array}{c}\text { Maximum } \\
\text { demand, MD }\end{array}$ & 466.5 & $\mathrm{~kW}$ & - \\
\hline MD total time & 12 & hours & - \\
\hline $\begin{array}{c}\text { Energy } \\
\text { required, } \mathrm{E}_{\text {req }}\end{array}$ & 5598 & $\mathrm{kWh}$ & $\begin{array}{c}466.5 \times 12 \\
=5598\end{array}$ \\
\hline $\begin{array}{c}\text { Power factor, } \\
\text { PF }\end{array}$ & 0.8 & - & - \\
\hline $\begin{array}{c}\text { Inverter } \\
\text { efficiency, } \\
\eta_{\text {inv }}\end{array}$ & 0.95 & - & - \\
\hline $\begin{array}{c}\text { Maximum } \\
\text { demand, MD }\end{array}$ & 613.81 & $\mathrm{kVA}$ & $\begin{array}{c}(466.5 / 0.8) \\
/ 0.95= \\
613.81\end{array}$ \\
\hline $\begin{array}{c}\text { Energy } \\
\text { required, } \mathrm{E}_{\text {req }}\end{array}$ & 7365.78 & $\mathrm{kVAh}$ & $\begin{array}{c}613.81 \times 12= \\
7365.78\end{array}$ \\
\hline
\end{tabular}

\section{Design of off-grid solar PV plant}

The design of an off-grid solar PV system consists of sizing PV modules and its associated components, also known as Balance of System (BOS). Many of these components have a long lifetime and little chance of mechanical failure since there are no moving parts. A solar PV system has an average lifetime of 20 to 25 years. Figure 2 shows the key components of a typical solar PV system.

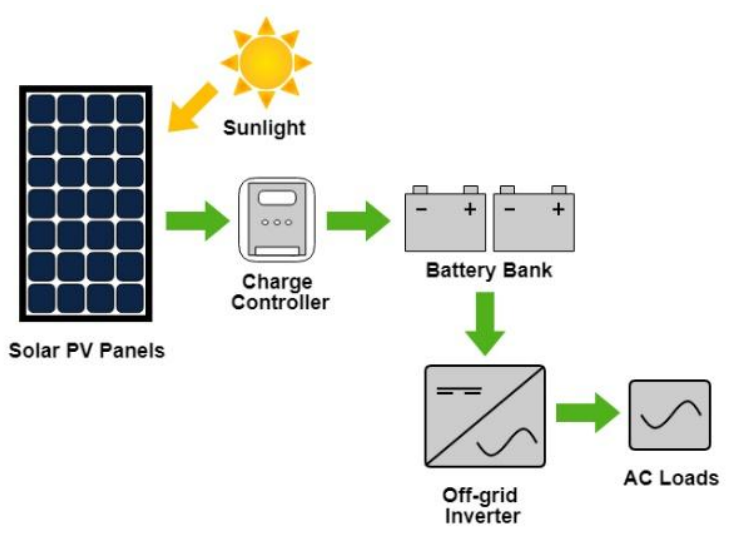

Fig. 2. Key components of a solar PV system.

Solar PV modules are the heart of the system and convert the sunlight to DC electricity. PV cells are devices that perform the conversion. The outputs from solar PV can be used directly to power DC loads if the working voltage is appropriate. Whereas, for $\mathrm{AC}$ systems, an inverter is required to convert DC to AC. Generation from PV system is directly dependent on weather conditions, particularly solar irradiation, temperature and shading (clouds, objects, etc.). The batteries are charged using DC power generated by PV modules via a charge controller and later channelled to the inverter for conversion to $\mathrm{AC}$ power as required by AC loads. Battery bank acts as storage and is necessary to provide uninterrupted supply of electricity in case when the solar power is not available such as during night time or cloudy days. The batteries also help to regulate the electricity supply to the load. It is very important to match the BOS and solar PV modules in terms of voltage and current, otherwise the system may fail to provide necessary power output.

\subsection{System voltage and load current}

The first step in design and sizing the solar PV system is to select the system voltage $\left(\mathrm{V}_{\text {sys }}\right)$ which is based on the MD. In this study, $240 \mathrm{~V}$ has been selected for MD higher than $500 \mathrm{~kW}$. Secondly, the load current ( $\mathrm{I}_{\text {load }}$ ) required for the system is calculated as follow:

$$
I_{\text {load }}=I_{\text {bat_MD }}=\frac{T M D}{V_{\text {sys }}}=\frac{613.81 \mathrm{k}}{240}=2.55 \mathrm{kA}
$$

\subsection{Battery sizing}

ROLLS flooded deep cycle batteries were selected for the charge storage. Datasheet of the battery can be found in reference [7]. The battery capacity $\left(\mathrm{C}_{\mathrm{Ah} \_ \text {req }}\right)$ in $\mathrm{Ah}$ to store the required energy $\left(E_{\text {req }}\right)$ was calculated as follow:

$$
C_{\text {Ah_req }}=\frac{E_{\text {req }}}{V_{\text {sys }}} \times \frac{K_{\text {storage }}}{\text { DOD }} \times t_{\text {aut }}=117967.57 \mathrm{Ah}
$$

Where, storage factor, $\mathrm{K}_{\text {storage }}=1.025$ (battery losses); days of autonomy, $\mathrm{t}_{\mathrm{aut}}=3$ days (energy that can be provided by battery alone without charging from solar PV or other sources); Depth of Discharge, DOD = 0.8 (selected from battery datasheet that can provide energy for the night time) Further, the discharge rate $\left(\mathrm{T}_{\text {dis }}\right)$ of the battery is given by:

$$
T_{\text {dis }}=\frac{E_{\text {req }}}{T M D} \times \frac{K_{\text {storage }}}{D O D} \times t_{\text {aut }}=46.12 \mathrm{Ah}
$$

Now, the nominal voltage of the battery, $\mathrm{V}_{\text {nom }}=32 \mathrm{~V}$ (taken from battery datasheet), and therefore battery capacity, $\mathrm{C}_{\text {bat }}=788 \mathrm{Ah}$ (given in battery datasheet for 8-hour rate usage) [7]. Hence, the number of batteries in series $\left(N_{s_{-} b a t}\right)$ and parallel $\left(N_{p_{-} b a t}\right)$ is calculated using the following equation:

$$
N_{S_{-} \text {bat }}=r \cdot u \cdot\left(\frac{V_{s_{s s}}}{V_{\text {nom_bat }}}\right)=\frac{240}{32}=7.5 \approx 8 \text { batteries }
$$

$N_{p_{-} \text {bat }}=r . u\left(\frac{C_{\text {Ah_req }}}{C_{\text {bat }}}\right)=\frac{117967.57}{788}=149.50 \approx 150$ batteries

Therefore, the total number of batteries $\left(N_{\text {tot_bat }}\right)$,

$$
N_{\text {tot_bat }}=N_{p_{-} \text {bat }} \times N_{S_{-} b a t}=150 \times 8=1200 \text { batteries }
$$

The battery bank capacity $\left(C_{A h_{-} b a t}\right)$ was found to be, 


$$
C_{A h \_b a t}=N_{p_{\_} \text {bat }} \times C_{\text {bat }}=150 \times 788=118200 \mathrm{Ah}
$$

\subsection{Number of PV modules required based on MPPT charge controller}

SunPower X-Series: X21-470-COM PV monocrystalline modules were selected for the present design [8]. The total number of PV modules $\left(\mathrm{N}_{\text {tot_pv_cc_mppt }}\right)$ per MPPT charge controller can be calculated using the following equation:

$$
\mathrm{N}_{\text {tot_pv_cc_mppt }}=\text { r.u. }\left[\frac{E_{\text {req }} \times \mathrm{f}_{\mathrm{o}}}{P_{\text {mp_corr }} \times \mathrm{PSH} \times \eta_{\text {ss }}}\right] \approx 7353 \text { modules }
$$

Where, r.u. is round up to next value; $\mathrm{f}_{\mathrm{o}}$ (oversupply coefficient of PV array) $=1.1$; $\quad$ Peak Sunshine Hours, PSH $=3.5 \mathrm{~h}$; Subsystem efficiency, $\eta_{\mathrm{ss}}=0.8 ; \mathrm{P}_{\mathrm{mp} \text { _corr }}$ is the corrected power rating of $\mathrm{PV}$ module given by,

$\mathrm{P}_{\text {mp_corr }}=\mathrm{P}_{\text {mp_stc }} \times \mathrm{K}_{\text {mm_p }} \times \mathrm{K}_{\text {temp_p }} \times \mathrm{K}_{\text {dir }} \times \mathrm{K}_{\text {age }}=393.57 \mathrm{~W}$

$\mathrm{P}_{\mathrm{mp} \_s t c}$ is the maximum power rating of the $\mathrm{PV}$ module $(470 \mathrm{Wp}$ at STC from solar PV module datasheet) [8]; $\mathrm{K}_{\mathrm{mm} \_\mathrm{p}}=0.97$ is the mismatch factor for the module power; $\mathrm{K}_{\mathrm{dir}}=0.97$ is the dirt factor; $\mathrm{K}_{\text {age }}=1$ is the age factor; $\mathrm{K}_{\text {temp_p }}$ is the temperature correction factor for the module and is calculated as follow:

$$
\mathrm{K}_{\text {temp_p }}=\left\{1+\left[\left(\frac{\% \gamma_{P_{\max }}}{100} \times\left[\mathrm{T}_{\text {cell }}-25\right]\right)\right]\right\}=0.89
$$

Where, $\% \gamma_{P_{\max }}=-0.29 \% /{ }^{\circ} \mathrm{C}$ is the temperature coefficient for maximum power (from the PV module datasheet [8]; $\mathrm{T}_{\text {cell }}=60^{\circ} \mathrm{C}$ is the typical PV module cell temperature.

\subsection{Charge controller sizing (MPPT type)}

Victron energy Smart-Solar charge controller MPPT $150 / 100$ model was selected for the proposed solar power plant. Datasheet of the selected charge controller can be found in reference [9]. Number of total PV modules per charge controller $\left(N_{\text {tot_pv_per_cc_mppt }}\right)$ is given by:

$$
N_{\text {tot_pv_per_cc_mppt }}=r . d \cdot\left[\frac{P_{\text {nom_cc_mppt }}}{P_{\text {mp_stc }} \times 0.9}\right] \approx 13 \text { modules } /
$$

charge controller

Where, $\mathrm{P}_{\text {nom_cc_mpt }}=5800 \mathrm{~W}$ is the nominal power of the MPPT charge controller [9] and $\mathrm{P}_{\mathrm{mp} \_ \text {stc }}=$ $470 \mathrm{~W}$ is the maximum power rating of the PV module [8].

$\mathrm{N}_{\text {s_max_cc_mppt }}$ is the maximum number of $\mathrm{PV}$ modules that can be attached to MPPT charge controller in series and is calculated as follow:

$$
N_{s_{-} \text {max_cc_mppt }}=r \cdot d \cdot\left[\frac{V_{\text {max } \_c \_m p p t} \times s f}{V_{\text {oc_max }}}\right] \approx 1 \text { module }
$$

Where, $\quad \mathrm{sf}=0.95$ is the safety factor; $\mathrm{V}_{\text {max_cc_mppt }}=145 \mathrm{~V}$ is the allowable maximum PV open circuit voltage by MPPT charge controller [9]; and $\mathrm{V}_{\text {oc_max }}$ is the maximum PV open circuit voltage and is calculated as follow:

$\mathrm{V}_{\mathrm{oc} \_ \text {max }}=\mathrm{V}_{\text {oc_stc }} \times\left\{1+\left[\frac{\% \gamma_{\mathrm{voc}}}{100} \times\left(\mathrm{T}_{\mathrm{m} \_ \text {min }}-25\right)\right]\right\}=92.62 \mathrm{~V}$

Where, $\mathrm{V}_{\text {oc_stc }}=91.5 \mathrm{~V}$ is the PV module open circuit voltage; $\mathrm{T}_{\mathrm{m}_{-} \min }=20^{\circ} \mathrm{C}$ is the minimum $\mathrm{PV}$ module temperature and $\% \gamma_{V_{O C}}$ is the coefficient of $\mathrm{V}_{\mathrm{oc}}$ and is calculated as follow:

$$
\% \gamma_{V_{o c}}=\left(\frac{\gamma_{V_{o c}}}{V_{o c}} \times 100 \%\right)=-0.244 \% /{ }^{\circ} \mathrm{C}
$$

Where, $\quad \gamma_{\mathrm{V}_{\mathrm{oc}}}=-223.2 \mathrm{mV}$ is the voltage temperature coefficient and $\mathrm{V}_{\mathrm{oc}}=91.5 \mathrm{~V}$ is the rated voltage of the PV module [8]. Therefore, final PV array configuration,

$$
\begin{array}{cccc}
\mathrm{N}_{\mathrm{p}_{-} \text {cc_mppt }} & \times \mathrm{N}_{\mathrm{S}_{-} \text {cc_mppt }} \leq & \mathrm{N}_{\text {tot_pv_per_cc_mppt }} \\
13 & \times 1 & \leq
\end{array}
$$

$\mathrm{N}_{\text {cc_mppt }}$ is the total number of MPPT charge controllers required and is calculated as follows:

$$
\begin{aligned}
& \mathrm{N}_{\text {cc_mppt }}=\text { r.u. }\left(\frac{\mathrm{N}_{\text {tot_pv_c__mppt }}}{\mathrm{N}_{\mathrm{p} \_c \_ \text {mpt }} \times \mathrm{N}_{\mathrm{N}_{\_} \text {cc_mppt }}}\right) \approx \\
& 566 \text { charge controllers }
\end{aligned}
$$

\subsection{Inverter sizing}

Inverter sizing $\left(\mathrm{P}_{\max \_ \text {inv }}\right)$ is done based on the maximum demand that is continuously occurring up to 30 minutes, and it has been calculated as follow:

$$
\mathrm{P}_{\text {max_inv }} \geq \sum \frac{P_{a c i}}{p f_{i}} \times \mathrm{f}_{\text {ovs }} \approx 760 \mathrm{~kW}
$$

Where, $\mathrm{P}_{\mathrm{aci}}=467 \mathrm{~kW}$ is the power demand; $\mathrm{pf}_{\mathrm{i}}=0.8$ is the power factor and $\mathrm{f}_{\mathrm{ovs}}=1.3$ is the oversize safety factor.

\subsection{Area required}

The area required to install the 7353 solar PV modules (dimension of one PV module is $2.067 \mathrm{~m} \times 1.046 \mathrm{~m}$ ) was calculated based on the previous study [10].

Number of PV modules per charge controller = 13 modules/array

Total width of each PV array

$$
=13 \times 1.046=13.598 \mathrm{~m}
$$

Number of arrays in PV field

$$
=\frac{7353}{13} \approx 56 \text { arrays }
$$

Number of arrays in a row $=13$

Length of the solar field

$$
=13 \times 13.598 \approx 177 \mathrm{~m}
$$

Number of rows in solar field 


$$
=\frac{566}{13} \approx 44
$$

Pitch distance between two arrays (including the module length of $2.067 \mathrm{~m})=3 \mathrm{~m}$

Width of the solar field

$$
=43 \times 3+2.067=131.067 \mathrm{~m}
$$

Land required for $\mathrm{PV}$ field

$$
\begin{gathered}
=177 \times 131.067 \approx 23,199 \mathrm{~m}^{2} \\
\approx 5.73 \text { acres }\left[1 \text { acre }=4047 \mathrm{~m}^{2}\right]
\end{gathered}
$$

Therefore, it was found that about $23,200 \mathrm{~m}^{2}$ or 5.73 acres' area is required for the present design which is quite large.

\section{Conclusions}

This study was carried out to design and size the 466.5 $\mathrm{kW}$ capacity off-grid solar PV power plant for an electric bus depot in Malaysia. The results showed that it is not only feasible to reduce the MD of the electric bus depot using solar PV plant but also the operational cost (of about MYR 12,000 per month) and $\mathrm{CO}_{2}$ emissions. For example, to offset $466.5 \mathrm{~kW} \mathrm{MD}$, it requires about 7353 PV modules, 566 MPPT charge controllers, $760 \mathrm{~kW}$ inverter size and a battery bank of 118,200 Ah (about 1200 batteries). However, the capital cost (CAPEX) to install this solar power plant is much higher (around 7 million MYR) because it involves energy storage or batteries. The present project also requires huge area to install the off-grid solar PV plant which may not be viable in cities. Future work will be to design and size the grid connected solar PV plant without energy storage and use the solar energy produced in the daytime to charge the electric buses which may significantly reduce the CAPEX, area and payback period thus gaining attraction of the project.

Authors would like to acknowledge financial assistance from Monash University Malaysia-Sunway Group of Companies grant no. SG-2018-02-ENG. Authors would also like to thanks and acknowledge Prasarana Malaysia Bhd. Staffs for their kind support and assistance in the project.

\section{References}

1. Suruhanjaya Tenaga (Energy Commission) Malaysia, Peninsular Malaysia Electric Supply Outlook, (2016)

2. MOT, Malaysia Stock taking Report on Sustainable Transport and Climate Change, (2017)

Retrieved from, http://www.mot.gov.my/SiteCollectionDocuments/ Darat/MY_StockTakingReport_Final.pdf, accessed on July 12, 2019

3. The Malaysian Reserve, Tapping on Malaysia's hydro potential, (2018) Retrieved date: 7/3/19

https://themalaysianreserve.com/2017/03/31/tapping -on-malaysias-hydro-potential/
4. Ataur Rahman, A.K.M Mohiuddin, Ahmad Faris Ismail, Prospects and challenges of electric vehicle adaptability: An energy review Malaysia; Energy, Education, Science and Technology, (2018)

5. Bin Ye, Jingjing Jiang, Lixin Miao, Peng Yang, Ji Li, Bo Shen; Feasibility study of a solar powered electric vehicle charging station model; Energies MDPI, (2015)

6. N. Chowdhury, C.A. Hossain, M. Longo, W. Yaïci ; Optimization of solar energy system for the electric vehicle at university campus in Dhaka, Bangladesh ; Energies MDPI, pp1-10, doi:10.3390/en11092433 (2018)

7. Flooded deep cycle battery datasheet 2019 ROLLS, Retrieved from,

http://www.rollsbattery.com/battery/16-ch33p/?pdf=7904\&fbclid=IwAR3u6ePUQgDdcUfdaGJTaOsaSrrmfi1rfLM9hrO07dUOPY70JsEcHcQHc, accessed on August 3, 2019

8. X-Series Commercial Solar Panels X21-470-COM SunPower, Retrieved from,

https://us.sunpower.com/sites/default/files/sunpower -x-series-commercial-solar-panels-x21- 470-comdatasheet-524935revb.pdf?fbclid=IwAR00EAhzZ5OZtP2U2VQK_p KpukGpRu NxA1xiYZkMLH16gKHOt5QWc1gil9E, accessed on August 3, 2019

9. Smart Solar Charge Controllers MPPT 150/45 up to 150/100 Victron energy, Retrieved from, https:/www.victronenergy.com/upload/documents/ Datasheet-SmartSolar-charge- controllerMPPT-150-45-up-to-150-100-EN.pdf, accessed on August 5, 2019

10. Mevin Chandel, G.D. Agrawal, Sanjay Mathur, Anuj Mathur; Techno-economic analysis of solar photovoltaic power plant for garment zone of Jaipur city Case Studies in Thermal Engineering, ELSEVIER (2013) 